\title{
Depoimento
}

\section{A interpretação do hino nacional do Timor Leste, Pátria}

\author{
Angela CALDERAZZO
}

Interpretar o hino nacional do Timor Leste, Pátria, foi uma experiência única para mim, porque me permitiu homenagear este país, conhecer a história desta nação e respeitar ainda mais o povo timorense.

Quando recebi o convite da Professora Nilce da Silva para cantar este hino, no curso sobre os países que falam a Língua Portuguesa, fiquei muito grata pela oportunidade de poder homenagear aqueles aos quais considero nossos irmãos.

Numa atitude de respeito à nação timorense, senti-me na obrigação de maior empenho para buscar transmitir, no momento da interpretação do hino, alguns aspectos do histórico de luta deste povo pela conquista de sua liberdade.

Percebendo a necessidade de mais informações sobre a história do país, realizei uma pequena pesquisa sobre as reações dos timorenses contra a colonização portuguesa e contra a posterior invasão de seu território pelos indonésios.

Durante esta preparação, pela leitura de textos e pelo filme Viva $o$ Timor, dirigido pela atriz Lucélia Santos, estabeleci contato com o imenso sofrimento pelo qual passou tal nação. Vi quantas vidas foram dizimadas, e quantas vozes foram caladas pela luta contra a Indonésia.

Também pude perceber que a letra expressa essa trajetória de resistência. Assim, pelo refrão (Pátria, Pátria, Timor Leste é nossa nação, Glória ao povo e aos heróis da nossa libertação), constatei que valorizava e resgatava a trajetória dos heróis anônimos que morreram pela independência do país. 
Ao me debruçar sobre a segunda parte da letra (Vencemos o colonialismo, gritamos abaixo o imperialismo, o inimigo dos povos até a vitória final, pelo caminho da revolução), analisei que havia um registro explícito e uma expressão da enorme luta e da postura revolucionária deste povo.

Após essa contextualização, comecei a refletir sobre o meu posicionamento como artista e como intérprete desta canção. Decidi, então, que a melhor forma de interpretação seria a que pudesse expressar a força que percebo no povo timorense, e o respeito que sinto pelas pessoas que morreram, e que ainda morrem pela nação.

Na data da apresentação do hino, 24 de março de 2006, às 17:00 h., no auditório da Faculdade de Educação da USP, em que tive como platéia os alunos do Ensino de Jovens e Adultos da Vila Brasilândia, os da Faculdade de Educação, além dos inscritos no curso, preocupei-me, primeiramente, em demonstrar o meu profundo respeito pelo sofrimento dos timorenses e a minha indignação pelo desamparo internacional durante o conflito com a Indonésia.

No transcorrer da interpretação do hino, Viva o Timor veio à tona. Imagens que documentaram a violência sofrida por aqueles que foram decapitados e/ou queimados, bem como o pranto coletivo das mães cujos filhos foram assassinados, revelaram quanto me marcaram e quão profundamente me sensibilizaram.

Confesso que eu poderia ter enfatizado o caráter musical da interpretação, mas o histórico de luta do país me emocionou e me envolveu de tal forma que ele ficou em segundo plano.

Diante da intensidade desta emoção, creio que me lembrarei sempre da letra do hino do Timor, a qual valoriza os heróis anônimos, renunciadores da própria vida em prol da liberdade de seu povo e de seu país. 
Após a pesquisa efetuada e a interpretação do hino, experiências que produziram um grande aprendizado, desejo à nação do Timor todo o bem, toda a paz, todo o respeito e toda a liberdade que merece.

Agradeço à Professora Nilce da Silva pelo convite, registro o meu reconhecimento e a minha admiração pela sua atuação em prol da inclusão social e do diálogo entre os países lusófonos.

\section{Autora:}

\section{Angela Calderazzo}

Mestranda em História social- PUC/SP, graduada em música- Faculdade de Música Carlos Gomes, graduanda em História - Centro Universitário UNIFIEO e professora de história da arte e da música da Escola Diretriz.

Rua Afonso Celso, 266 - Vila Mariana - São Paulo/SP. Fone: (11) 9825 549150838612

Residência: Rua Mário, 240 - Lapa - São Paulo/SP - 05048-010

Fone (11) 38736920

angelacalderazzo@yahoo.com.br

\section{Como citar este depoimento:}

CALDERAZZO, Angela. A interpretação do hino nacional do Timor Leste, Pátria - Depoimento. Revista ACOALFAplp: Acolhendo a Alfabetização nos Países de Língua portuguesa, São Paulo, ano 1, n. 1, 2006. Disponível em: 〈http://www.acoalfaplp.net>. Publicado em: setembro de 2006. 